\title{
Disperis and Epipogium (Orchidaceae): two new generic record for the flora of Odisha
}

\author{
Truptirekha Kar ${ }^{1}$, Maloth Mohan ${ }^{1}$ and Kishore Kumar Mandal2区 \\ 1 Similipal Tiger Reserve, Bhanjpur, Baripada, Odisha -757002, India \\ 2P. G. Department of Botany, North Orissa University, Baripada, Odisha -757003, India \\ 凶Corresponding author: Kumar.kishore718@gmail.com
}

\section{डिस्पेरिस एवं इपिपोजियम (ऑकिडेसी) : ओड़ीशा के वनस्पतिजात के लिए दो नए वंशपरक अभिलेख}

\author{
त्रुप्तिरेखा कर, मालोथ मोहन एवं किशोर कुमार मंडल
}

\section{सारांश}

ओड़िसा राज्य के लिए दो नवीन वंशपरक अभिलेख के रूप में दो ऑर्किड जातियां डिस्पेरिस नीलघेरेन्सिस वाइट एवं इपिपोजियम रोजियम (डी. डॉन ) लिंडल प्रथम बार दर्ज किये गये । प्रस्तुत शोध पत्र में इन दोनों जातियों का विस्तृत वर्गिकी विवरण, वितरण पर टिप्पणी एवं आसानी से पहचान के लिए एक फोटोप्लेट दी गयी है ।

\section{ABSTRACT}

Two orchid species viz. Disperisneilgherrensis Wight and Epipogium roseum (D. Don) Lindl. are reported as new distributional record for the state of Odisha. These genera are recorded first time for the flora of Odisha. Detailed taxonomic description, notes on distribution and photo plates are provided for easy identification.

Keywords: Disperis, Epipogium, Flora, Orchidaceae, Similipal

\section{INTRODUCTION}

The genus Disperis Sw. with about 70 species is well represented in Africa, Madagascar and its adjacent Indian Ocean islands (Manning, 1999; La Croix \& al., 2002). The genus has also been recorded from tropical Asia, ranging from India to Thailand, the Philippines and Guinea
(Seidenfaden, 1969). The genus is well known for its extremely complicated flower morphology and structure; with various fused floral parts and highly elaborated lip bearing appendages (Kurzweil \& Linder, 1991; Kurzweil, 2005). Similarly, the genus Epipogium J.G. Gmel. ex Borkh., is a terrestrial achlorophyllous, myco-heterotropic orchid with about 04 species (WCSP, 2017) and 
distributed in tropical Africa, temperate \& tropical Asia, Australia and Europe.

During our recent floristic exploration in Similipal Biosphere Reserve, few interesting plants belonging to these two genera of family Orchidaceae were collected, which were identified as Disperis neilgherrensis Wight and Epipogium roseum (D. Don) Lindl., A thorough scrutiny of literature (Haines, 1924; Mooney, 1950; Misra, 1990, 1997, 2004, 2007, 2014; Saxena \& Brahmam, 1995; Bahali $\&$ al. 2008) revealed that these species are hitherto not reported from Odisha. Hence, in the present communication, these two species are reported as new addition to the flora of Odisha. A brief taxonomic description, photoplates along with information on phenology and distribution are provided here.

\section{TAXONOMIC TREATMENT}

Disperis neilgherrensis Wight, Icon. Pl. Ind. Orient. 5: t. 1719. 1851; Hook. f., Fl. Brit. India 6: 169. 1890; Fischer in Gamble, Fl. Pres. Madras 3: 1032. 1957; Abraham \& Vatsala, Introd. Orch. 208. 1981; Kurzweil, Blumea 50: 145. 2005. Disperis zeylanica Trimen, J. Bot. 23: 245. 1885; Hook. f., Fl. Brit. India 6: 169. 1890; Manilal, Fl. Silent Valley 278. 1988. Disperis monophylla Blatter ex Fischer in Gamble, Fl. Pres. Madras 3: 1033. 1957.

Terrestrial herbs, with ovoid tubers. Stem delicate, erect, slender, flaccid, 5-12 cm long. Leaves 2-3, ovate to suborbicular, $1-1.8 \times 0.5-1.5 \mathrm{~cm}$, cordate, amplexicaul at base, sessile, apex acute. Flowers solitary, terminal, white or greenish white with green spots, sessile, 2-lipped, 1-1.5 $\mathrm{cm}$ across. Dorsal sepals and petals connate to form a hood over the column; dorsal sepal c. $7 \times 2 \mathrm{~mm}$, linearlanceolate, 3 -veined; lateral sepals $c .7 \times 5 \mathrm{~mm}$, obliquely obovate, deflexed over the ovary. Petals broadly falcate, c. $7 \times 5 \mathrm{~mm}$, incurved at apex, acute. Lip c. $4 \times 5 \mathrm{~mm}$, ' $\mathrm{Y}$ ' shaped with recurved arms. Column c. $2 \mathrm{~mm}$ long with an appendage at base. Anther 2-celled; pollinia attached to the apex of rostellum arms. Capsules ellipsoid, ribbed, c. $1.5-2 \mathrm{~cm}$ long.

Flowering and Fruiting: June - September.

Specimens Examined: INDIA, Odisha: Similipal Biosphere Reserve, Meghasini, 20.08.2017, Kar and Mandal 1227 (Similipal Tiger Reserve Herbarium); Tamil Nadu: Coimbatore, Varadimalai, 16.05.1911, CEC Fischer 2761 (CAL); Akkamalai, 1700 m, 23.07.1978, M. Chandrabose 57270 (CAL); Nagahur Road, Yercard, 04.06.1983, E. Varjravelu 77724 (CAL).
Habitat and Ecology: Rare in Similipal Biosphere Reserve at 900-1000 m altitude, under moist and shady localities of semi-evergreen forests.

Distribution: India, Odisha (Present report); Kerala; Tamil Nadu; Karnataka; Thailand, Philippines and Guinea.

Epipogium roseum (D. Don) Lindl., J. Proc. Linn. Soc. Bot. 1: 177. 1857; Manilal, Fl. Silent Valley 279. 1988; V.S. Ramach. \& V.J. Nair, Fl. Cannanore 453. 1988; Sasidh. \& Sivar., Fl. Pl. of Thrissur For. 440. 1996. Limodorum roseum D. Don, Prodr. Fl. Nepal. 30. 1825. Epipogium nutans (Blume) Reichb.f., Bonplandia 5: 36. 1857; Hook.f. Fl. Brit. India 6: 124. 1890; Fischer in Gamble, Fl. Pres. Madras 8: 1460. 1928 ('Epipogum'). Podanthera pallida Wight, Icon. Pl. Ind. Orient. 5: 22. t.1759. 1851.

Slender, saprophytic herbs, up to $45 \mathrm{~cm}$ high. Rhizome tuberous, ellipsoid, wrinkled, $2-5 \times 2-3 \mathrm{~cm}$. Stem fleshy, hollow, white or pale yellow; scales ovate to lanceolate, white, membranous. Inflorescence in lax racemes, several-flowered; floral bracts ovate-lanceolate, 6-15 × 3-5 $\mathrm{mm}$. Flowers drooping, not expanding widely, white with faint purple spots on lip; pedicel 3-7 mm long. Dorsal sepal linear-lanceolate, 7-11 $\times$ 2-3 mm, 3-veined, apex subacute; lateral sepals linear, $6.5-10 \times 2-3 \mathrm{~mm}$, acute. Petals slightly shorter and wider than sepals, 6-10 $\times 2.5$ $3.5 \mathrm{~mm}$, apex acute to acuminate. Lip ovate - lanceolate, concave, 9-14 $\times$ 5-7 mm, dotted with dull pink spots, spurred at base, margins crenulate; spur projecting backward, cylindrical, nearly parallel to ovary. Column truncate, 2-3 mm; anther sub-globose; ovary broadly ovoid, 5-8 mm long. Capsules ovoid-ellipsoid.

Flowering and Fruiting: May - August.

Specimens Examined: INDIA, Odisha: Similipal Biosphere Reserve, Upper Barhakamuda, 26.06.2017, Kar and Mandal 1059 (Similipal Tiger Reserve Herbarium). Kerala: Idukki Dist., 700 m., 18.02.1983, C. N. Mohanan 76249 (MH); Cannanore Dist., 550 m., 22.01.1979, V. S. Ramachandran 59146 (MH); Palghat Dist., 880 m., 22.04.1980, V. J. Nair 67292 (MH). Arunachal Pradesh: Dibang Valley, 1300 m., 18.05.1998, M. Bhaumik 1845 (CAL).

Habitat and Ecology: Rare saprophytic orchid growing in semi-evergreen forests floor of Similipal Biosphere Reserve at 850-900 m altitude.

Distribution: India, Odisha (Present report); Tamil Nadu; Kerala; Karnataka, Arunachal Pradesh; Srilanka, Nepal, Australia and Malaysia. 


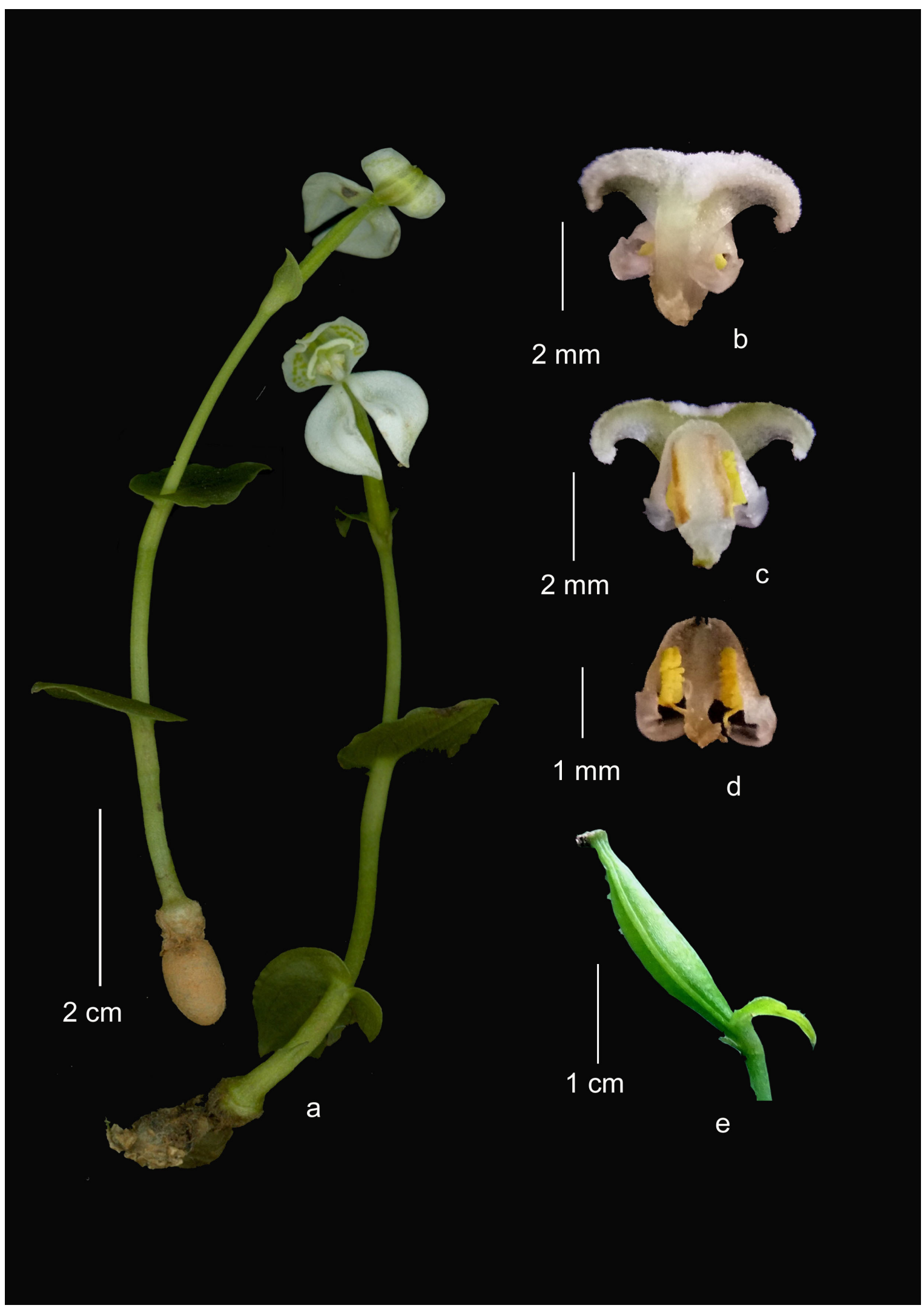

Fig 1. Disperis neilgherrensis Wight, a. Habit, b\&c. Lip with column, d. Polinia with anther cap, e. Capsule. 


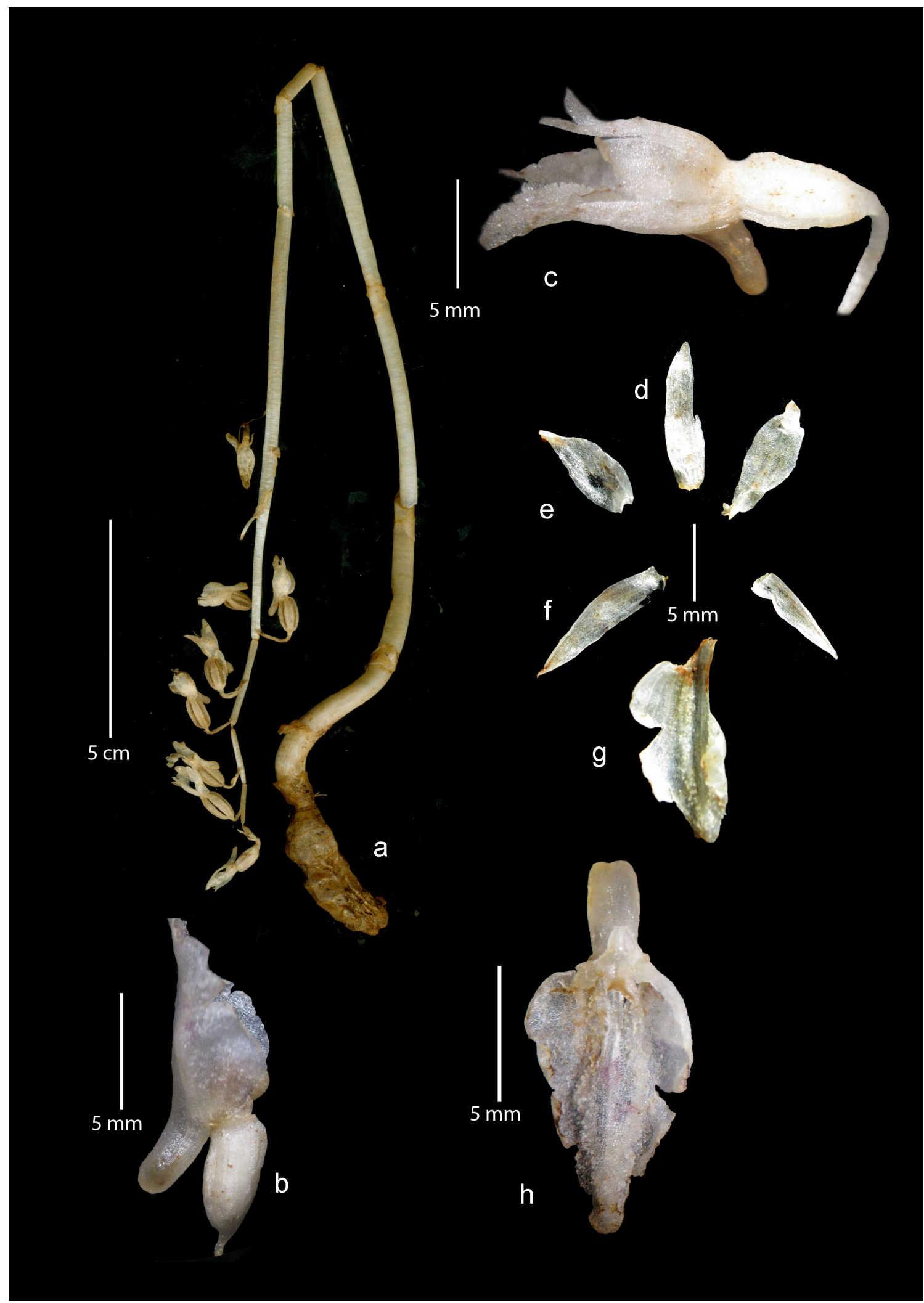

Fig 2. Epipogium roseum (D.Don) Lindl., a. Habit, b\&c. Flower, d. Dorsal sepal, e. Petal, f. Lateral sepal, g. Lip, h. Spur and lip. 


\section{ACKNOWLEDGEMENTS}

The authors are thankful to Principal Chief Conservator of Forest (Wildlife) \& Chief Wildlife Warden, Odisha, Bhubaneswar for his kind permission to carry out the field study. We would also like to thank Dr. Paramjit Singh, Director, Botanical Survey of India, Kolkata for permission to consult herbarium and library.

\section{REFERENCES}

BAHALI, D. D., D. K. AGRAWALA AND H. J. CHOWDHERY. 2008. Similipal Tiger Reserve. In Floristic Diversity of Tiger Reserves of India. pp. 418-441. Botanical Survey of India, Kolkata.

HAINES, H. H. 1924. The Botany of Bihar and Orissa. Part VI, Adlard and Sons, London. Pp. 1150-1182.

KURZWEIL, H. AND H. P. LINDER 1991. A comparative study of the floral morphology in the genus Disperis (Orchidaceae). Beitr. Biol. Pflanzen 66: 433-477.

KURZWEIL, H. 2005. Taxonomic studies in the genus Disperis in South East Asia. Blumea 50: 143-152.

LA CROIX, I., J. BOSSER AND P. J. CRIBB. 2002. The genus Disperis (Orchidaceae) in Madagascar, the Comores, the Mascarenes and the Seychelles. Adansonia, ser. 3, 24: 55-87.
MANNING, J. 1999. Disperis. In: H. P. Linder \& H. Kurzweil, Orchids of Southern Africa, pp. 299-320. Balkema, Rotterdam.

MISRA, S. 1990. An enumeration of the Orchids of Similipal hills in Orissa, India. Pl. Sci. Res. 11(2): 73-84.

MISRA, S. 1997. Orchids of Similipal forest. In: Similipal: A Natural Habitat of Unique Biodiversity. P.C. Tripathy \& S.N. Patro (Eds.) Orissa Environmental Society, Bhubaneswar.

MISRA, S. 2004. Orchids of Orissa. pp 1-774, Bishen Singh Mahendra Pal Singh, Dehra Dun.

MISRA, S. 2007. Orchids of India: A glimpse, pp. 1-402, Bishen Singh Mahendra Pal Singh, Dehra Dun.

MISRA, S. 2014. Orchids of Odisha: A handbook. pp. 1-424, Bishen Singh Mahendra Pal Singh, Dehra Dun.

MOONEY H. F. 1950. Supplements to the Botany of Bihar and Orissa. Catholic Press, Ranchi.

SAXENA, H. O. AND M. BRAHMAM 1995. The Flora of Orissa. Vol. 3. pp 1323-2008.Orissa Forest Development Corporation, Ltd. Bhubaneswar.

SEIDENFADEN, G. 1969. Contributions to the orchid flora of Thailand. Bot. Tidsskr. 65: 100-162.

WCSP. 2017. Kew Royal Botanic Gardens. World Checklist of Selected Plant families. Available at: http://apps.kew.org/ wcsp/home (Accessed: June 2017). 